\section{Kirurgihistorie - en fremtidsrettet reiseskildring}

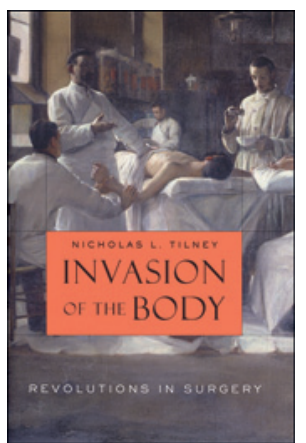

Nicholas L. Tilney Invasion of the body

Revolutions in surgery. 358 s, ill. Cambridge, MA: Harvard University Press, 2011.

Pris USD 30

ISBN 978-0-674-06228-3

Forfatteren var inntil nylig transplantasjonskirurg ved Brigham and Women's Hospital og professor ved Harvard Medical School i Boston. Han er nå åpenbart en aktiv og skriveglad pensjonist en historieforteller av rang. Denne boken er stinn av fakta om faglige milepæler og vitenskapelige gjennombrudd. Selv om prestisjeområder som åpen hjertekirurgi og organtransplantasjon får stor plass, trekker han inn en rekke nyvinninger innen andre kirurgiske områder, og også innen anestesi, utvikling av antibiotika, perioperativ overvåkning og bildediagnostikk.

Forfatteren formidler fakta og viser til referanser på en ryddig måte. I tillegg krydrer han kirurgihistorien, gjerne preget av tørre årstall og triumfer, med levende historier fra virkeligheten. Han reflekterer rundt enkeltpasienters sykdom og skjebne, slik de til enhver tid ble håndtert gjennom denne tidsperioden. Dette er fascinerende skildringer om utviklingen innen moderne medisin generelt, og om kirurgien spesielt - på liv og død. Språket er mer variert og rikholdig enn man ofte møter i amerikanske tekster.

Forfatterens vindu til verden er åpent, ikke minst mot Europa. Han anerkjenner og trekker frem de europeiske kirurgipionerene, spesielt fra England, Tyskland og Frankrike. Sitt eget toårige opphold i Europa som ung kirurg har åpenbart gitt ham en utvidet horisont, noe han også formidler i teksten.

Gjennom 12 kapitler følger vi utviklingen de siste 100 årene med store endringer i organisering, utdanning og utøvelse av kirurgifaget. Dagens høyt profilerte utdanningssykehus som Johns Hopkins, Mayo Clinic og Brigham and Women's Hospital så dagens lys for vel 100 års siden, og det samme gjorde etableringen av American College of Surgeons. I et eget kapittel, Making a Surgeon, Then and Now, kommer det tydelig frem at forfatteren er opptatt av både utdannelsen og dannelsen av kirurger: $\AA$ utdanne en selvstendig, velfungerende kirurg tar minst 15 år etter medisinstudiet de fem første årene lærer man å operere, de neste fem årene lærer man når man skal operere, og de siste fem årene lærer man når man $i k k e$ skal operere. Han er sikkert ikke den eneste som har tenkt i de baner. Når han i avslutningskapitlet drøfter de mange uløste utfordringene, understreker han at dette er en bok som innbyr til refleksjon, og som samtidig gir inspirasjon.

Det er gode referanser til hvert kapittel, og et godt stikkordregister til slutt gir boken verdi også som referanse. Innbindingen og papiret er solid.

Forfatterens engasjement og lidenskap for sitt fag og sine pasienter, men også for sine utdanningskandidater og studenter, er tydelig. Han forteller og formidler til alle som vil høre og lære, og det bør være mange også utenfor de kirurgiske fagområdene. På den måten kan flere unngå å møte fremtidens faglige utfordringer helt historieløse.

\section{Et uhørt forslag}

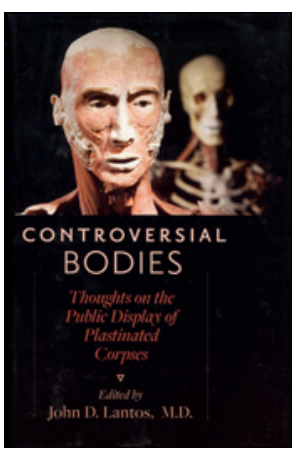

John D. Lantos, red.

Controversial bodies

Thoughts on the public display of plastinated corpses. 145 s. Baltimore, MD: The Johns Hopkins University Press, 2011. Pris USD 35 ISBN 978-1-4214-0271-0

I snart 20 år har Günther von Hagens' utstilling med plastinerte lik turnert verden rundt under navnet Body Worlds. Det startet i Tokyo i 1995. Utstillingen har vært innom Skandinavia, men foreløpig ikke i Norge. På verdensbasis er utstillingen sett av mer enn 30 millioner og må betegnes som en gedigen kommersiell suksess. De første årene ble utstillingen satt opp i mer eller mindre lugubre messehaller, men utover i 2000-årene, og særlig etter at Body Worlds slo gjennom i USA, er det nå gjerne tekniske museer og vitenskapssentre som huser den. Günther von Hagens er tatt inn i varmen. Plastmenneskene tjener et didaktisk formål, de illustrerer livsstilssykdommers skadevirkninger, og de er formet som atleter som utfolder seg med fritidssysler. Pengene fosser inn. En rekke foranstaltninger skal hindre at besøkende føler seg støtt. Men oppnås det? Ikke helt.

Motforestillinger og et energisk, kritisk engasjement har fulgt von Hagens fra første stund. Som tittelen tydelig viser, tar denne boken tak i det kontroversielle, og takk for det.

Controversial bodies består av tolv artikler og et etterord. De fleste bidragsyterne er tilknyttet medisinske læresteder, innen fag som bioetikk, psykiatri, medisinsk humanisme og medisinsk teologi. Selv så jeg særlig frem til bidragene av Linda Schulte-Sasse og Barbara Maria Stafford. Førstnevnte har skrevet skarpt om von Hagens tidligere, og sistnevnte har skrevet et vidunderlig verk med tittelen Body critisism (1991), som er et tidlig eksempel på en tverrfaglig studie innen medisin og humaniora. Særlig Staffords bidrag er spennende. Hun beskriver overgangene fra en tidligere tiders biokjemisk og molekylær biologi, til vår tids syntetiske biologi, en «newgenics». De plastinerte likene illustrerer denne tesen. De består av $30 \%$ biologisk og $70 \%$ syntetisk materiale.

Ett av bidragene peker seg ut, og det er skrevet av Geoffrey Rees. Han skriver om fremtidens offentlige anatomifremvisninger og tar utgangspunkt i paragrafen om hjernedød, som grensen for død. Ifølge ham er det å benytte hjernedøde kropper til offentlige fremvisinger bare en naturlig forlengelse av det å stille menneskelik til disposisjon. Den hjernedøde kroppen har et mye større didaktisk potensial. Tenk på alle sykdommene som lar seg vise live med en hjernedøds kropp! Jeg leser noen sider og tenker at nå vil vel Rees snart avblåse sin egen spøk. Men når han så kommer til mulige innvendinger, blir det derimot tydelig at han har påtatt seg å være djevelens advokat. Det er bisart. Jeg velger å lese det som et satirisk innlegg.

Det er mange spennende og poengterte resonnementer i Controversial bodies. Den kan leses med stort utbytte av alle som vil sette seg inn i klokt formulerte, etiske, moralske, didaktiske og filosofiske betenkeligheter ved Body Worlds.

\section{Espen Stueland \\ Voss}

